The part of the building already constructed will house the Heat and General Physics Section of the Physics Department, with part of the radiology and sound work. It is hoped during the next few years that sanction will be obtained for the erection of the wings, so that the remainder of the Radiology Section and the temperature standardisation work can be transferred from the dwelling-houses and other buildings in which they are at present accommodated. The quadrangle will be completed by the Acoustics Building, the erection of a section of which has recently been approved.

\section{The Pulp-Wood Market in the United States.}

CNDER the arresting headline "Russia seizes Canada's Market", the Monetary Times of Toronto (Jan. 2, 1931) discusses the position of the pulp-wood market, a position which is not without interest for Europe. In 1924, under the heading "The Mistaken Idea that Canada has a Monopoly in Wood ", the Canadian Pulpwood Association in a memorandum to the Royal Commission on Pulpwood wrote: "Contrary to the prevailing idea, it must not be overlooked that if the American is forced to turn away from Canada for raw materials, he will find that we have not by any means a monopoly. For instance, wood from Russia, in large quantities, is already freely quoted, by substantial concerns, for delivery at Atlantic seaports. If the U.S. operator has the Canadian door shut in his face, he will naturally consider it to his interest to encourage forestry conservation and development intensively in the United States to ensure independence as far as possible."

The memorandum went on to point out that research would be stimulated, that so far as possible existing American hardwoods would be utilised, and that already there had been a remarkable development in the use of the long-leaf southern pine in the kraft industry. In short, that there was a possibility that, in the attempt to take advantage of America's extremity by the threat of pulp-wood export restrictions, Canada might find that she had jeopardised a valuable trade connexion in paper products, encouraged her chief customer to develop her own resources, whilst unconsciously encouraging her trade with other countries.

To-day these predictions are coming true. America has been busily engaged in investigating every source of pulp-wood supply, an absolute necessity to her, owing to her enormous consumption of pulp. One of the new sources of supply has proved to be Russia. This year, Russian shipments of the highest quality of wood, amounting to some 300 cords, are being delivered in the eastern States at the same price as Canadian wood. Further, Canada gave transportation preference to the Russian wood; for the latter, landed at the Canadian ports of Sorel or Three Rivers, was for a time carried to the United States by Canadian railways at lower freight rates than these railways gave to Canadian wood for precisely the same movement.

The other possibility predicted, that America would undertake research with the object of endeavouring to make use of materials of her own not previously utilised for the pulp trade, has also been verified by the already mentioned development of the long-leafed southern pine in the kraft industry; and there is another interesting outcome. Dr. C. H. Herty, former president of the American Chemical Society, recently announced to the Atlanta Chamber of Commerce that he had succeeded in producing high grade newsprint paper from southern slash pine, cooked in the same digester and under the same conditions as spruce. The importance of this research work becomes evident when it is understood that there are vast reserves of this timber in the southern States, and that this variety of southern pine had always been regarded as the least capable of producing regular newsprint.

The above description of the present position in the pulp industry in the New World carries some important lessons for Europe. It displays the close and accurate study made of world-wide forest resources and the thorough knowledge of the pulp-wood industry which exists on the other side of the Atlantic. It also throws a strong light on the attitude taken up and ideas expressed since the War in some quarters in Britain upon the small influence the Russian coniferous forests were capable of exerting on the markets.

\section{University and Educational Intelligence.}

LONDON.-The degree of D.Sc. has been conferred on the following: W. Youngman, for a thesis entitled "Further Studies in the Cytology of the Hibiscex", with two subsidiary contributions; S. E. Hollingworth, for a thesis entitled "The Glaciation and Physiographic Development of the Eden Catchment Basin West of that River, and the Drumlins of Edenside and the Solway Basin ", with two subsidiary contributions ; Lin. L. Lee (Rothamsted Experimental Station), for a thesis entitled "The Influence of Geology and Climates on Soil Types" (Jour. S.-E. Agric. Coll., June 1931); A. N. Puri (Rothamsted Experimental Station), for a thesis entitled. "Studies in Soil Colloids" (Memoirs of Dept. of Agriculture, 1930; Soil Science, 1930-31); A. J. Maslen (Chelsea Polytechnic), for a thesis entitled "The Structure of Mesoxylon Platypodium and Mesoxyliodes" (Annals of Botany, July 1930); L. R. Underwood (Imperial College-City and Guilds College and East London College), for a thesis entitled "The Combustion of an Oil Jet in an Engine Cylinder".

THE following fellowships for the year 1931-32 have been awarded by the Salters' Institute of Industrial Chemistry and approved by the Court of the Salters' Company : J. L. Sweeten (St. Catherine's College, Cambridge) and Norman Stuart (Imperial College, London). Fellowships have been renewed to: D. L. Hodge (Imperial College, London), D. J. Branscombe (University College, Exeter), J. Hofton (Caius College, Cambridge), and H. G. Simpson (East London College). The Salters' Institute has also awarded one hundred and thirteen grants-in-aid to young men and women employed in chemical works, to facilitate their further studies.

The Ramsay Memorial Fellowship Trustees have made the following awards of new fellowships for the year 1931-32: Dr. B. K. Blount, a fellowship of $£ 300$, tenable for two years, at the University of Oxford; Mr. Ragnar Ericson, a Swedish fellowship of $£ 300$, tenable for two years, at the Imperial College, London; Dr. George Karagunis, a Greek fellowship of $£ 400$, tenable for one year, at University College, London; Dr. J. Lens, a Netherland fellowship of $£ 300$, tenable for two years, at University College, London; Dr. Y. Urushibara, a Japanese fellowship of $£ 400$, tenable for two years, at University College, London. The Trustees have renewed the following fellowships for the year 1931--32: Mr. W. R. Angus (British fellow), University College, London, and Dr. James Bell (Glasgow fellow), University College, London. 